\title{
PENGARUH BIMBINGAN TEKNIK MENYUSUI TERHADAP SIKAP IBU HAMIL TRIMESTER III DALAM PEMBERIAN ASI EKSKLUSIF
}

\author{
La Ode Alifariki ${ }^{\star \bowtie}$, Wa Ode Syahrani Hajii ${ }^{* *}$
}

\begin{abstract}
Abstrak
Posisi dan cara menyusui yang benar sangat penting dalam pemberian ASI, seorang ibu dan bayi pertamanya mungkin mengalami berbagai masalah hanya karena tidak mengetahui posisi dan cara menyusui yang benar misalnya cara menaruh bayi pada payudara ketika menyusui, isapan bayi yang mengakibatkan putting susu terasa nyeri, dan masih banyak masalah lainnya. Oleh karena itu, seorang ibu memerlukan seseorang yang dapat membimbingnya dalam merawat bayi termasuk dalam menyusui. Tujuan penelitian ini adalah untuk mengetahui pengaruh bimbingan teknik menyusui yang benar terhadap sikap ibu hamil trimester III dalam pemberian ASI eksklusif. Penelitian ini menggunakan metode quasyexperiment dengan one-group pre-test post-test desain dan dilaksanakan pada bulan Agustus $2019 \mathrm{di}$ Puskesmas Poasia Kota Kendari. Populasi penelitian adalah semua ibu hamil trimester III sebanyak 320 orang. Adapun jumlah sampel sebanyak 32 responden dengan kriteria umur kehamilan 28 minggu atau lebih dan ibu hamil yang hadir pada saat pelaksanaan Posyandu. Analisis data menggunakan uji t dependen. Hasil penelitian menunjukkan bahwa sebelum bimbingan teknik menyusui dalam pemberian ASI eksklusif didapatkan nilai rerata sikap ibu sebesar 56,92. Sesudah bimbingan teknik menyusui dalam pemberian ASI ekslusif didapatkan rerata nilai sikap ibu sebesar 65,19 . Hasil analisis $t$-test berpasangan menunjukkan adanya pengaruh bimbingan teknik menyusui yang benar terhadap sikap ibu hamil trimester III dalam pemberian ASI eksklusif dengan $p=0,024(p<0,05)$. Jadi, dapat disimpulkan bahwa bimbingan teknik menyusui berpengaruh terhadap sikap ibu hamil dalam pemberian ASI eksklusif di Puskesmas Poasia.
\end{abstract}

Kata kunci: ASI eksklusif, bimbingan teknik menyusui, sikap.

\section{THE INFLUENCE OF LACTATING GUIDANCE TO THE THIRD TRIMESTER OF PREGNANT WOMEN'S ATTITUDES ON EXCLUSIVE BREASTFEEDING}

\begin{abstract}
The correct position and method of breastfeeding is very important in breastfeeding, a mother and her first baby may experience various problems just because they do not know the correct position and way of breastfeeding such as how to put the baby on the breast when breastfeeding, baby sucking that causes nipple pain, and many other problems. Therefore, a mother needs someone who can guide her in caring for the intended baby in breastfeeding. The purpose of this study was to determine the effect of proper breastfeeding technique guidance to the attitude of the third trimester pregnant women on exclusive breastfeeding. This research used quasy-experimental method with a one-group pre-test post-test design. This research was conducted in August 2019 at the Poasia Health Center in Kendari City. The study population was all third trimester pregnant women in Poasia Health Center as many as 320 women. The number of samples was 32 respondents with gestational age 28 weeks or more and pregnant women who were come to the Integrated Health Center (Posyandu). The data was analyzed using a dependent t-test. The results showed that before the guidance of breastfeeding techniques in exclusive breastfeeding the mean of mother's attitudes was 56.92. After the guidance of breastfeeding techniques in exclusive breastfeeding, the mean of mother's attitude was 65.19 . The results of the paired t-test showed that correct breastfeeding technique guidance affects the attitude of third trimester pregnant women in exclusive breastfeeding $(p=0.024$; $p<0.05$ ). So, it can be concluded that the guidance of breastfeeding techniques influences the attitude of pregnant women in exclusive breastfeeding at the Poasia Health Center.
\end{abstract}

Keywords: attitude, exclusive breastfeeding, guidance for breastfeeding technique.

*Program Studi Keperawatan, Fakultas Kedokteran, Universitas Halu Oleo

* Departemen Keperawatan Anak, Fakultas Kedokteran, Universitas Halu Oleo

凶E-mail: ners_riki@yahoo.co.id 


\section{Latar Belakang}

WHO dan UNICEF merekomendasikan pemberian nutrisi yang optimal bagi bayi baru lahir yakni melalui strategi global pemberian ASI eksklusif selama enam bulan. ${ }^{1}$ America Academy of Pediatrics merekomendasikan pemberian ASI eksklusif kepada bayi selama minimal 6 bulan dan dapat dilanjutkan minimal sampai bayi berusia 12 bulan. ASI merupakan nutrisi terbaik yang secara khusus ditujukan bagi bayi baru lahir karena mengandung berbagai komponen antibodi, nutrisi yang lengkap dan mudah dicerna oleh bayi baru lahir dibandingkan dengan susu formula. ${ }^{2}$

Banyak zat dalam ASI yang tidak terdapat sama sekali, atau hanya ada dalam jumlah kecil pada susu formula. Selain itu, dalam proses menyusui yang benar, bayi akan mendapatkan perkembangan jasmani, emosi, maupun spiritual yang baik dalam kehidupannya. ${ }^{3}$

Menurut penelitian yang dilakukan oleh Wagner et al. ${ }^{4}$ terkait minat ibu hamil dalam menyusui menjadi gambaran sangat penting bagi keberlangsungan proses menyusui di kemudian hari. Sangat disayangkan, sebagian dari ibu menyusui di Amerika gagal dalam mewujudkan minat mereka dalam menyusui, pada akhirnya mereka memberi bayinya susu formula atau menghentikan pemberian ASI lebih awal dari yang telah mereka rencanakan. Dari ibu hamil yang merencanakan untuk hanya memberi ASI saja selama lebih dari 2 bulan setelah melahirkan, $47 \%$ pada akhirnya memberikan susu formula sejak hari ke-30 dan ke-60 pasca melahirkan, dan $21 \%$ berhenti menyusui setelah 60 hari pasca melahirkan. lbu nifas yang baru saja melahirkan biasanya menggambarkan beberapa minggu pertama menyusui sebagai masa-masa yang sangat sulit, dengan banyak masalah tidak terduga yang timbul. ${ }^{4}$ Masalah yang timbul termasuk puting susu lecet atau pecah-pecah, payudara bengkak, saluran susu tersumbat dan mastitis atau abses payudara. ${ }^{5}$

Petugas kesehatan sebagai pelayan kesehatan diharapkan melakukan berbagai upaya dalam meningkatkan serta mendukung pemberian ASI serta memberikan penyuluhan dan nasehat yang objektif dan konsisten pada ibu hamil dan ibu yang baru melahirkan tentang pemberian ASI. Peran bidan juga sangat penting dalam membantu ibu pada waktu pertama kali memberi ASI yaitu penentuan posisi menyusui yang baik dan benar. ${ }^{6}$

Posisi dan cara menyusui yang benar sangat penting dalam pemberian ASI. Seorang ibu dan bayi pertamanya mungkin mengalami berbagai masalah hanya karena tidak mengetahui posisi dan cara menyusui yang benar, misalnya cara menaruh bayi pada payudara ketika menyusui, isapan bayi yang mengakibatkan putting susu terasa nyeri, dan masih banyak masalah lainnya, oleh karena itu seorang ibu memerlukan seseorang yang dapat membimbingnya dalam merawat bayi termaksud dalam menyusui. ${ }^{7}$

Hasil Penelitian Riksani ${ }^{8}$, faktor yang mempengaruhi cara menyusui yang benar antara lain rendahnya pengetahuan dan informasi tentang menyusui yang benar, dan tidak jarang fasilitas kesehatan yang justru memberikan susu formula kepada bayi yang baru lahir. Pengalaman dan pendidikan wanita sejak kecil juga mempengaruhi sikap mereka yang berkaitan dengan menyusui.

Penelitian yang dilakukan oleh Rahayu berjudul gambaran praktik ibu tentang menyusui yang benar menunjukkan sebagian besar ibu praktik menyusui kurang benar sebanyak 19 orang $(59,38 \%) .{ }^{9}$ Begitupun hasil penelitian Ratih yang mendapatkan $65,5 \%$ ibu menyusui melakukan praktik menyusui yang salah. ${ }^{10}$ 
Berdasarkan data Survey Demografi Kesehatan Indonesia (SDKI) Tahun 2017 menunjukkan jumlah cakupan bayi yang mendapat ASI eksklusif sebesar 61,33\%. Cakupan pemberian ASI eksklusif di Provinsi Sulawesi Tenggara sebanyak 64,05\%, persentase tertinggi cakupan pemberian ASI esklusif terdapat di Provinsi Nusa Tenggara Barat yaitu $87,35 \%$, sedangkan persentase terendah terdapat di Papua yaitu $15,32 \% .{ }^{11}$

Berdasarkan fenomena tersebut, maka perlu dilakukan penelitian tentang pengaruh bimbingan teknik menyusui yang benar terhadap sikap ibu hamil trimester III dalam pemberian ASI eksklusif.

\section{Bahan dan Metode}

\section{Desain Penelitian}

Penelitian yang dilakukan menggunakan metode eksperimen yaitu kegiatan percobaan yang bertujuan untuk mengetahui suatu gejala atau pengaruh yang timbul (sikap ibu hamil trimester III) sebagai akibat dari suatu perlakuan tertentu (bimbingan teknik menyusui), dengan rancangan quasy-experiment dan menggunakan one group pretest-posttest design. Penelitian dilakukan di Puskesmas Poasia Kota Kendari pada bulan Agustus 2019. Penelitian ini telah mendapatkan persetujuan dari Dewan Komite Etik Kesehatan Universitas Halu Oleo dengan nomor surat: 2817/UN29.20/PPM/2019.

\section{Populasi dan Sampel Penelitian}

Populasi penelitian adalah semua ibu hamil trimester III di Puskesmas Poasia Kota Kendari sebanyak 320 orang. Sampel penelitian sebanyak 32 responden. Variabel dependen dalam penelitian ini adalah sikap ibu dalam pemberian ASI eksklusif, sedangkan variabel independen adalah bimbingan teknik menyusui. Teknik sampling penelitian adalah purposive sampling dengan kriteria inklusi berdomisili di wilayah kerja Puskesmas Poasia Kota Kendari, bersedia menjadi responden. Variabel sikap dinilai menggunakan kuesioner dengan rentang nilai 1-4 (skala likert), yakni sangat setuju, setuju, tidak setuju, sangat tidak setuju berisi 10 pernyataan positif dan negatif. Pada pernyataan positif, jawaban sangat setuju diberi skor 4 , setuju diberi skor 3 , tidak setuju diberi skor 2 dan sangat tidak setuju diberi skor 1 . Sebaliknya, pada pernyataan negatif, jika jawaban sangat setuju diberi skor 1 , setuju diberi skor 2, tidak setuju diberi skor 3 dan sangat tidak setuju diberi skor 4 . Pelaksanaan intervensi dilakukan selama 25 menit dengan cara memberikan edukasi berupa contoh teknik menyusui yang baik dan benar.

\section{Analisis Statistik}

Data dianalisis menggunakan univariate dan bivariate (uji $t$ berpasangan) pada nilai signifikansi $a=0,05$. Data diproses dengan program SPSS 16.0 for windows kemudian disajikan dalam bentuk tabel dan dideskripsikan dalam bentuk narasi.

\section{Hasil}

Penelitian ini mendapatkan usia paling banyak adalah $20-35$ tahun sebanyak $78,1 \%$, dengan tingkat pendidikan terbanyak pada pendidikan SMA sebanyak $62,5 \%$, jenis perkerjaan terbanyak adalah ibu rumah tangga sebanyak $65,5 \%$, dan paritas tertinggi adalah kurang dari 3 kali yaitu sebanyak $59,4 \%$ (Tabel 1).

Pengaruh bimbingan teknik menyusui pada 32 responden menunjukkan sebelum bimbingan didapatkan nilai rerata adalah 56,92 , nilai median adalah 55 dan nilai minmax adalah 45-70. Lalu, setelah bimbingan teknik menyusui menunjukkan nilai rerata adalah 65,19 , nilai median adalah 67 dan nilai min-max adalah 45-77 (Tabel 2).

Sebelum diberikan bimbingan didapatkan nilai standar deviasi sebesar 9,301, dan sesudah bimbingan teknik menyusui didapatkan nilai 7,810 . 
Hasil analisis uji $t$ dependen pada Tabel 3 diperoleh nilai t hitung adalah 4.605 dengan nilai $p=0,024<a=0,05$ yang artinya $\mathrm{H}_{0}$ ditolak dan $\mathrm{H}_{1}$ diterima yang menunjukkan bah- wa ada pengaruh bimbingan teknik menyusui dalam pemberian ASI eksklusif terhadap sikap ibu hamil trisemester III di Puskesmas Poasia Kota Kendari.

Tabel 1. Karakteristik responden.

\begin{tabular}{|c|c|c|}
\hline \multirow{2}{*}{ Variabel } & \multicolumn{2}{|c|}{ ASI Eksklusif $(n=32)$} \\
\hline & $n$ & $\%$ \\
\hline \multicolumn{3}{|l|}{ Usia ibu (tahun) } \\
\hline$<20$ & 5 & 15,6 \\
\hline $20-35$ & 25 & 78,1 \\
\hline 35 & 2 & 6,2 \\
\hline \multicolumn{3}{|c|}{ Tingkat pendidikan } \\
\hline S1/S2 & 5 & 15,6 \\
\hline SMA & 20 & 62,5 \\
\hline SMP & 3 & 9,4 \\
\hline SD & 4 & 12,5 \\
\hline \multicolumn{3}{|l|}{ Jenis pekerjaan } \\
\hline PNS & 3 & 9,4 \\
\hline Petani & 5 & 15,6 \\
\hline Wiraswasta & 3 & 9,4 \\
\hline IRT & 21 & 65,5 \\
\hline \multicolumn{3}{|l|}{ Paritas } \\
\hline$\geq 3$ kali & 13 & 40,6 \\
\hline$<3$ kali & 19 & 59,4 \\
\hline
\end{tabular}

Tabel 2. Nilai rerata sikap sebelum dan sesudah bimbingan teknik pada ibu menyusui di Puskesmas Poasia Kota Kendari

\begin{tabular}{lccc}
\hline Tahap intervensi & Rerata & Median & Min-Max \\
\hline Sebelum & 56,92 & 55 & $45-45$ \\
Sesudah & 65,19 & 67 & $70-77$ \\
\hline
\end{tabular}

Tabel 3. Pengaruh bimbingan teknik menyusui terhadap sikap ibu hamil dalam pemberian ASI eksklusif di Puskesmas Poasia Kota Kendari.

\begin{tabular}{lcc}
\hline Sikap Ibu Hamil dalam Pemberian ASI Ekslusif & t-test & p-value \\
\hline $\begin{array}{l}\text { Sebelum bimbingan } \\
\text { Sesudah bimbingan }\end{array}$ & 4,605 & 0,024 \\
\hline
\end{tabular}




\section{Pembahasan}

Hasil penelitian menunjukkan bahwa dari 32 responden didapatkan peningkatan rerata sikap ibu menyusui sebesar 65,19 setelah diberikan bimbingan teknik menyusui, jika dibandingkan dengan nilai rerata sebelum diberikan bimbingan yaitu sebesar 56,92. Peningkatan ini juga diamati pada nilai median setelah bimbingan teknik menyusui yaitu 67 dibandingkan dengan sebelum pelaksanaan bimbingan teknik menyusui adalah 55 . Nilai min-max sebelum pelaksanaan bimbingan teknik menyusui adalah 45-70. Hal ini menunjukkan bahwa nilai sikap paling rendah yang diperoleh sebelum pelaksanaan bimbingan teknik menyusui adalah 45 dan paling tinggi adalah 70 . Sedangkan setelah pelaksanaan bimbingan teknik menyusui, nilai sikap minimum adalah tetap 45 sedangkan nilai maksimum meningkat menjadi 77 .

Sikap negatif ibu yang dominan terhadap teknik menyusui dipengaruhi oleh pernyataan ibu yang masih banyak merasakan kekhawatiran bila bayi tidak mendapatkan air susu pertama, tidak merasa takut jika keluarga akan memberikan makanan selain ASI sebelum bayi berusia 6 bulan, tidak setuju jika hanya dengan memberikan ASI bayi akan menjadi sehat dan terhindar dari penyakit, tidak merasa mampu memberikan ASI eksklusif pada bayi selama 6 bulan dan tidak yakin dengan hanya memberikan ASI saja akan membuat bayi tumbuh menjadi anak yang cerdas.

Sikap ibu sesudah mendapatkan bimbingan teknik menyusui cenderung mengalami perubahan. Hal ini dibuktikan dengan persentase sikap positif ibu meningkat dibanding sebelum bimbingan dilakukan. Hasill penelitian ini menunjukkan bahwa dari 32 responden, terdapat 26 responden $(81,2 \%)$ bersikap positif terhadap teknik menyusui dan sebanyak 6 responden $(18,8 \%)$ masih bersikap negatif terhadap teknik menyusui menyusui walaupun sudah menerima bimbingan.

Perubahan sikap ini dipengaruhi oleh adanya bimbingan yang dilakukan peneliti dalam memberi pengetahuan tentang teknik menyusui. Hal ini dapat dibuktikan dengan pernyataan beberapa responden yang dominan berubah dibandingkan dengan pernyataan sebelum bimbingan. Sikap setuju terhadap ketidakkhawatiran untuk tidak mendapatkan air susu pertama, perubahan sikap yang merasa tenang apabila memberikan ASI sesuai jadwal, merasa khawatir jika keluarga akan memberikan makanan selain ASI sebelum bayi berumur 6 bulan, setuju dengan memberikan ASI bayi akan menjadi lebih sehat dan terhindar dari penyakit, merasa tidak tenang jika tidak memenuhi kebutuhan ASI untuk bayi karena banyak manfaat yang terkandung dalam ASI, dan makin yakin dan sangat setuju dengan memberikan ASI saja akan membuat bayi tumbuh menjadi anak yang cerdas. Hal ini karena telah mengetahui adanya asam lemak tak jenuh rantai panjang atau asam dokosaheksanoat (DHA) yang terkandung dalam ASI. Asam lemak ini sangat penting untuk perkembangan otak. Selain DHA, ASI juga mengandung ARA, protein, taurin, dan beberapa enzim yang penting untuk perkembangan jaringan saraf. ${ }^{3}$

Pada penelitian ini, jenis intervensi yang diberikan pada ibu hamil trimester III adalah bimbingan teknik menyusui yang benar. Bimbingan merupakan bagian dari pendidikan kesehatan yang dapat diartikan sebagai bantuan yang diberikan kepada individu tersebut untuk menjadi mandiri, dengan menggunakan berbagai bahan, interaksi, nasehat dan gagasan dalam suasana asuhan berdasarkan norma-norma yang berlaku. ${ }^{12}$ Menurut Notoatmodjo, sikap adalah suatu reaksi atau respons yang masih tertutup dari seseorang terhadap suatu stimulus atau objek. ${ }^{13}$ 
Sikap merupakan kesiapan untuk berinterkasi suatu objek dengan cara-cara tertentu. Kesiapan yang dimaksud adalah kecenderungan potensial untuk berinteraksi dengan cara tertentu apabila individu dihadapkan pada stimulus yang menghendaki adanya respons. ${ }^{14}$

Sikap adalah suatu proses penilaian yang dilakukan oleh seorang individu terhadap suatu objek. Objek yang disikapi individu dapat berupa benda, manusia atau informasi. Proses penilaian seorang terhadap suatu objek dapat berupa penilaian positif dan negatif. Sesuatu yang dipelajari dan menentukan bagaimana individu bereaksi terhadap situasi serta menentukan apa yang dicari oleh individu dalam hidupnya. Maka, dapat disimpulkan bahwa sikap adalah suatu reaksi atau respons berupa penilaian yang muncul dari seorang individu terhadap suatu objek. Sikap juga dapat dikatakan sebagai suatu perwujudan adanya kesadaran terhadap lingkunganya.

Pada Tabel 3 dapat diketahui bahwa hasil analisis uji $t$ dependen diperoleh nilai $t$ hitung $=4,605$ dengan nilai $p=0,024<a=$ 0,05 yang artinya ada pengaruh bimbingan teknik menyusui dalam pemberian ASI eksklusif terhadap sikap ibu hamil trimester III di Puskesmas Konda Kabupaten Konawe Selatan tahun 2019. Bimbingan merupakan pemberian informasi untuk meningkatkan pengetahuan terhadap apa yang ada di lingkungan sekitar dan dapat memengaruhi sikap. Hal ini sejalan dengan teori Green dalam Notoatmodjo (2012), bimbingan merupakan pemberian informasi atau pengetahuan yang merupakan salah satu faktor predisposisi dalam pembentukan perilaku dan sikap. ${ }^{13}$

Selain itu, sikap terdiri dari 3 komponen pokok yaitu kepercayaan atau keyakinan, ide dan konsep terhadap objek, kehidupan emosional atau evaluasi orang terhadap objek, kecenderungan untuk bertindak (tend to behave). ${ }^{13}$ Ketiga komponen tersebut secara bersama-sama membentuk sikap yang utuh (total attitude). Dalam menentukan sikap yang utuh ini, pengetahuan, pikiran dan keyakinan serta memegang peranan penting.

Penelitian yang dilakukan oleh Erlin (2014) dengan metode penelitian preeksperimen menggunakan uji Wilcoxon ditemukan ada pengaruh sikap terhadap perilaku pemberian ASI minggu pertama pada ibu nifas..$^{15}$ Penelitian Pratama juga menunjukkan ada pengaruh pendidikan kesehatan terhadap perubahan pengetahuan, sikap dan perilaku tentang perilaku hidup bersih dan sehat siswa SDN 1 Mandong. Hasil analisis data pengetahuan diperoleh paired sample test $=9,543 p=0,001$. Hasil analisis data sikap diperoleh paired sample test sebesar $=$ 11,122 dengan nilai $p=0,001$ dan perubahan perilaku dengan nilai Wilcoxon rank test sebesar $=3,411$ dengan nilai $p=0,001 .{ }^{15}$

Perilaku ibu menyusui dalam memberikan ASI eksklusif akan banyak ditentukan oleh bagaimana kepercayaan dan perasaan ibu tentang ASI eksklusif. Ibu menyusui yang memiliki penilaian/ kepercayaan dan memiliki pengetahuan yang luas yang disertai dengan perasaan positif mengenai kognisinya tentang ASI eksklusif, maka ia akan cenderung memberikan ASI eksklusif. Ibu yang memiliki sikap positif terhadap pemberian ASI eksklusif, maka akan cenderung untuk memberikan ASI secara eksklusi pula. Pada umumnya ibu memang memiliki sikap positif tentang pemberian ASI eksklusif dan banyak di antara mereka yang ingin memberikan ASI secara eksklusif. 16

Namun, selain sikap banyak hal yang mempengaruhi dalam pemberian ASI eksklusif seperti pendidikan, pengetahuan, nilainilai atau adat budaya, pendapatan keluarga, ketersediaan waktu, kesehatan ibu, dukungan keluarga, dukungan petugas kesehatan. 
Ibu yang memiliki sikap positif memang sudah berencana untuk memberikan ASI secara eksklusif. Namun, saat mereka menemukan kendala seperti ASI tidak keluar, maka ibu merasa kasihan karena anaknya rewel sehingga ibu mengambil keputusan untuk memberikan susu formula pada bayinya. Hal inilah yang menjadi alasan mengapa ada beberapa ibu menyusui yang setelah mendapatkan informasi bimbingan teknik menyusui tetap tidak memberikan ASI secara eksklusif pada bayinya.

Perubahan sikap sebelum dan setelah bimbingan merupakan keberhasilan dalam pemberian pemahaman kepada ibu hamil tentang posisi dan perlekatan menyusu. Hal terpenting dalam proses menyusui adalah posisi ibu pada saat menyusui yaitu ibu harus merasa aman dan rileks terhadap berbagai macam posisi menyusu seperti duduk, berdiri atau berbaring. Hal ini menjadi penting karena beberapa riset menemukan faktor tersebut dapat mempengaruhi produksi ASI yaitu apabila teknik menyusui tidak benar dapat menyebabkan putting susu lecet dan menjadikan ibu enggan menyusui sehingga berakibat pada bayi itu sendiri.

Manfaat dari penelitian ini agar dapat memberikan informasi bimbingan terhadap perubahan sikap pada sasaran yang membutuhkan informasi. Sikap negatif responden yang sebelumnya masih belum memahami pada akhirnya dapat berubah dengan adanya bimbingan yang benar baik dari petugas kesehatan. Hal ini dibuktikan dengan meningkatnya persentase sikap ibu terhadap pernyataan-pernyataan yang diberikan dibandingkan sebelum bimbingan dilakukan.

\section{Kesimpulan}

Penelitian ini menyimpulkan bahwa bimbingan teknik menyusui berpengaruh terhadap sikap ibu hamil dalam pemberian ASI eksklusif di Puskesmas Poasia.

\section{Daftar Pustaka}

1. WHO (Would Health Organization). Infant and Young Child Feeding: Model Chapter for Textbooks for Medical Students and Allied Health Professionals. France: Lancet Publishing Group. 2009.

2. Perry, E. Shannon., Hockenberry, J.M., Lowdermilk, L.D. WD. Maternal Child Nursing Care. $4^{\text {th }}$ Edition. St. Louis: Mosby-Elsevier. 2010.

3. Roesli U. Inisiasi Menyusu Dini Plus ASI Eksklusif. Jakarta: Pustaka Bunda. 2008.

4. Wagner DR, Heyward VH. Measures of Body Composition in Blacks and Whites: A Comparative Review. Am J Clin Nutr. 2000; 71(6):1392-402.

5. Astutik RY. Payudara dan Laktasi. Jakarta: Salemba Medika. 2014.

6. Anggraini Y. Asuhan Kebidanan Masa Nifas. Yogyakarta: Pustaka Rihama. 2010.

7. Bahiyatun. Buku Ajar Asuhan Kebidanan Nifas Normal. Jakarta: EGC. 2013.

8. Riksani R. Keajaiban ASI. Jakarta: Salemba Medika. 2012.

9. Rahayu, S. Gambaran Praktik Ibu tentang Cara Menyusui yang Benar. Jurnal Keperawatan Maternitas. 2011; 9 (3).

10. Ratih. Hubungan Teknik Menyusui dengan Kejadian Puting Susu Lecet. Di dalam: Prosiding Nasional APIKESAKBID Citra Medika Surakarta. 2014.

11. Kementerian Kesehatan RI. Profil Kesehatan Indonesia. Jakarta: Balitbangkes RI. 2018.

12. Wulandari. Asuhan Kebidanan Nifas. Yogyakarta: Mitra Cendika. 2009.

13. Notoatmodjo S. Promosi Kesehatan dan IImu Perilaku. Jakarta: PT. Rineka Cipta. 2012.

14. Azwar. Sikap Manusia: Teori dan Pengukurannya. Yogyakarta: Pustaka Pelajar. 2016. 
15. Erlin. Pengaruh Penyuluhan Cara Menyusui yang Benar terhadap Pemberian ASI pada Minggu Pertama pada Ibu Nifas di RS. PKU. Muhammadiyah Yogyakarta. STIKES Aisyiyah Yogyakart. 2014.
16. Pratama. Pengaruh Pendidikan Kesehatan terhadap Perubahan Pengetahuan, Sikap dan Perilaku tentang Kebiasaan Berperilaku Hidup Bersih dan Sehat Siswa SDN 1 Mandong. Universitas Muhammadiyah Surakarta. 2013. 